\title{
Abundance and toxicity of Planktothrix rubescens in the pre-alpine Lake Ammersee, Germany
}

\author{
Bernhard Ernst, Stefan J. Hoeger, Evelyn O'Brien, Daniel R. Dietrich* \\ Human E Envirommental Toxicology, University of Konstanz, P.O. Box X-918, D-78457 Konstanz, Gernany
}

A B S TRACT

Regular occurrences of the cyanobacterium Planktot/rix nubescens have been observed in several lakes that have undergone recent re-oligotrophication, e.g. Lake Ammersee. Planktothrix species are known to produce microcystins, potent phosphatase inhibitors that have been associated with morbidities and mortalities in humans and animals. The aim of this study was to characterise the temporal and spatial abundance and toxicity of $P$. rubescens in Lake Ammersee.

P. rubescens cell densities and biovolumes were calculated via fluorescence image analyses. $P$.

Keywords:

Planktothrix

Cyanobacteria

Re-oligotrophication

Phosphorous

Nitrogen

Transparency

Secchi depth

Microcystin

Coregonids

Fish rubescens was present during the entire observation period from 1999 to 2004 , albeit at different cell densities. Maximum biovolumes of $45 \mathrm{~cm}^{3} \mathrm{~m}^{-2}$ were observed in May 2001. Filaments were regularly distributed over the entire water column during winter and stratified in distinct metalimnic layers during summer, reacling maximum cell densities of $\leq 15,000$ (winter) and $\leq 77,000$ cells ml $^{-1}$ (summer). The results demonstrate that $P$. rubescens abundance is strongly influenced by water transparency, i.e. illumination in the metalimnion. Morcover, the $P$. rubescens abundance appears to result from regular phosphate depletion in the epilimnion, possibly additionally benefiting from high nitrogen loads.

Microcystin (MC) was detectable in 27 and 38 of 54 seston samples via HPLC and Adda-ELISA measurements, respectively. The main microcystin congeners in the seston samples were [Asp $\left.{ }^{3}\right]-\mathrm{MC}-\mathrm{RR}$ and $\left[\mathrm{Asp}^{3}, \mathrm{Dhb}^{7}\right]-\mathrm{MC}-\mathrm{RR}$. Microcystin concentrations correlated significantly with the respective phycoerythrin (PE)-concentrations. The variation in the MC/PE-ratios was low suggesting that the microcystin production of $P$. rubescens in Lake Ammersee is consistent and indicates that the appearance of $P$. rubescens coincides with measurable microcystin levels. Moreover, the observation of pronounced metalimnic oxygen depletions appears to be causally related to recurring high $P$. rubescens abundance.

In conclusion the results suggest that aquatic organisms such as indigenous fish populations (e.g. coregonids) are regularly confronted with potentially adverse $P$. rubescens densities, which might provide a possible explanation for the often observed impaired health and growth retardation of coregonid populations in $P$. rubescens containing pre-alpine lakes.

\section{Introduction}

Cyanobacteria are important constituents of phytoplankton communities and ubiquitous in lakes of different nutritional status. Approximately 50 of 2000 known cyanobacterial species are recognised to produce toxic molecules, e.g. alkaloids and peptides (Sivonen and Jones, 1999). Many of these toxins have

\footnotetext{
- Corresponding author. Tel.: +49 7531 883518; fax: +49 7531883170.

E-mail address: daniel.dietrich@uni-konstanz.de (D.R. Dietrich)

1 Cyclic heptapeptides, sharing the common structure cyclo(-Adda-D-Glu-Mdla$D$-Ala- $L-X-D-M e A s p-L-Z$ ) where $X$ and $Z$ are variable $L$-amino acids, Adda is an uncommon anino acid 3-amino-9-methoxy-2,6,8,-trimethyl-10-phenyl-4,6,-decadienoic acid. D-MeAsp is 3-methylaspartic acid. and Mdha is $\mathrm{N}$-methyldehydroalanine.
}

been associated with mortalities of wild and domestic animals as well as severe human intoxications. Among these toxins, microcystins ${ }^{1}$ are most frequently found and have gained attention due to their potent inhibition of protein phosphatases and associated morbidities and mortalities in humans and animals (Falconer, 2001; Briand et al., 2003).

Microcystin-producing cyanobacteria are present in coastal and inland waters, primarily in naturally eutrophic waterbodies and waters that have experienced nutritional enrichment due to anthropogenic influences (eutrophication) (Bartram et al., 1999). However, in contrast to presently eutrophicated water bodies with Anabaena sp., Aphanizomenon sp. and Microcystis aeruginosa blooms, regular mass occurrences of the cyanobacterium Planktothrix rubescens have been observed in lakes that had undergone recent re-oligotrophication. This especially includes lakes in the 
Table 1

Size and nutritional status in (pre-) alpine lakes with documented $P$, rubescens abundance during the last decade

\begin{tabular}{|c|c|c|c|c|}
\hline Country/lake & Size $\left(\mathrm{km}^{2}\right)$ & Trophic status & Abundance & References \\
\hline \multicolumn{5}{|l|}{ Austria } \\
\hline Wörthersee & 19.4 & Mesotrophic & $2000-2006$ & Kärntner Seenberichte (2000-2007) www.kis.ktn.gv.at \\
\hline Ossiacher See & 10.8 & Mesotrophic & $2000,2003-2006$ & Kärntner Seenberichte (2000-2007) www.kis.ktn.gv.at \\
\hline Millstätter See & 13.3 & Oligo-mesotrophic & $2000-2003,2005-2006$ & Kärntner Seenberichte (2000-2007) www.kis.ktn.gv.at \\
\hline Mondsee & 16.6 & Mesotrophic & $1994-1997,2001$ & Kurmayer et al. (2004), Teubner et al. (2004) \\
\hline \multicolumn{5}{|l|}{ France } \\
\hline Lac du Bourget & 42 & Mesotrophic & $1996,1999,2001$ & Jacquet et al. (2005). Lehoulanger et al. (2002) \\
\hline \multicolumn{5}{|l|}{ Germany (Bavaria) } \\
\hline Ammersee & 46.6 & Mesotrophic & 1996, $1998-2001$ & Teubner et al. (2004), Ernst et al. (2001) \\
\hline Chiemsee & 79.9 & Mesotrophic & 2004,2006 & Ernst (unpuplished data) \\
\hline Starnberger See & 56.4 & Mesotrophic & 1997,2005 & Ernst (unpublished data), Nixdorf et al. (2004) \\
\hline \multicolumn{5}{|l|}{ Italy } \\
\hline Lago Maggiore & 212.5 & oligo-mesotrophic & $1995-1999$ & Morabito et al. (2002) \\
\hline Lago di Garda & 368.0 & Oligo-mesotrophic & $1995-2000$ & Salmaso $(2000,2002)$ \\
\hline Lago d'Iseo & 62 & Mesotrophic & Regularly & Salmaso $(2000)$ \\
\hline Lago di Como & 146.0 & Mesotrophic & $1997-1999$ & Buzzi (2002), Bettinetti et al. (2000) \\
\hline Lago di Pusiano & 5.3 & Eutrophic & 2001,2002 & Legnani et al. (2005) \\
\hline \multicolumn{5}{|l|}{ Switzerland } \\
\hline Lac de Neuchatel & 217.9 & Oligo-mesotroph & $1999-2004$ & www.die3seen.ch \\
\hline Zürichsee & 65.1 & Mesotrophic & $1993-2000$ & Hoeger et al. (2005). Walsby and Schanz (2002) \\
\hline Lago di Lugano & 48.8 & Meso-eutroph & Regularly & Salmaso $(2000)$ \\
\hline Thunersee & 47.8 & Oligo-mesotroph & Regularly & Ochsenbein and Mattmann (2003) \\
\hline Bielersee & 37.8 & Meso-eutroph & $2000-2006$ & www.die3seen.ch \\
\hline Murtensee & 22.8 & Mesotroph & $2004-2006$ & www.die3scen.ch \\
\hline Sempachersee & 14.4 & Eutroph & $1989-1997$ & Bürgi and Stadelmann (2002), Mez (1998) \\
\hline
\end{tabular}

pre-mountainous areas of the Alps characterised by an ice-age modulated landscape of hills and valleys (pre-alpine regions) (Table 1).

The mass occurrence of $P$. rubescens is predominantly ascribed to two forms of specialisation providing for an ecological niche as well as a competitive advantage over green algae: i.e. an efficient regulation of buoyancy via semi-permeable gas vesicles enabling $P$. rubescens filaments to stratify effectively in the water column and the production of allophycocyanin, phycocyanin and phycoerythrin. photopigments enabling maximum utilisation of light energy and existence under low light conditions (Feuillade, 1994; Walsby and Schanz, 2002). Consequently, P. rubescens stratify in compact metalimnic layers overshadowed by the epilimnic community during summer stratification. Moreover, $P$. rubescens filaments can grow at low light conditions during circulation in the late autumn to early spring months or even below an ice cover during winter (Blikstad-Halstvedt et al., 2007).

Metalimnic blooms of Planktothrix species are often observed to co-occur with marked oxygen deficiencies in the metalimnion (Lindholm and Meriluoto, 1991: Salmaso, 2000; Ernst et al., 2001: Buzzi, 2002: Krupa and Czernas, 2003). Indeed, the senescence of cyanobacterial blooms may generate an increased oxygen demand and consequently result in massive oxygen depletion. In addition, cyanobacterial senescence provides for the release of cyanobacterial toxins (Malbrouck and Kestemont, 2006). In comparison to other cyanobacterial species, Planktothrix sp. have been shown to contain the highest concentrations of microcystin per gram dry weight (Fastner et al., 1999b). Depending on the P. rubescens abundance, toxicity and distribution, both the release of cyanobacterial toxins as well as metalimnic oxygen deficiencies may result in adverse effects on aquatic organisms (Sivonen and Jones.

\footnotetext{
${ }^{2}$ Coregonids (whitefish; Coregomus sp.) are among the dominant species of the ichthyofauna in most pre-alpine lakes, and, due to their high economic value, of great importance for the professional fishery.
}

1999: Wiegand and Pflugmacher, 2005), especially on coregonids ${ }^{2}$ (Ernst et al., 2006a, 2007).

The aims of this study were therefore

- to characterise the spatial and seasonal abundance of $P$. rubescens in Lake Ammersee,

- to characterise the variability of microcystin content in $P$. rubescens and

- to investigate the temporal co-occurrence of alterations in $P$. rubescens abundance and metalimnic oxygen depletion.

Exemplified by the indigenous coregonid (whitefish) population, the findings are finally discussed in the context of possible adverse effects on aquatic organisms.

\section{Materials and methods}

\subsection{Chemicals}

All reagents and solvents employed were of analytical or chromatographic grade and quality and purchased from Fluka (Switzerland), Merck (Germany), Riedel de Haen (Germany). Roth (Germany) or Sigma (Germany). Water was purified to $18.2 \mathrm{M} \Omega \mathrm{cm}^{-1}$.

\subsection{Study location}

Lake Ammersee is a typical pre-alpine lake, located in the south of Germany at an altitude of $553 \mathrm{~m}$. The lake arose following the retreat of the glaciers at the end of the last ice age. Lake Ammersee is elongated in south-north orientation ( $16 \mathrm{~km}$ length and $2.9 \mathrm{~km}$ average width) and formed like a tube with steep shores on both west and east sides. Limnologically, Lake Ammersee is a dimictic lake (turning over twice a year) with a surface area of $46.6 \mathrm{~km}^{2}$, a total volume of $1750 \times 10^{6} \mathrm{~m}^{3}$ and a maximum and average depth of 81.1 and $37.5 \mathrm{~m}$, respectively (Grimminger, 1982). Complete 
Table 2

Time-points and intervals of sampling during the six-year survey

\begin{tabular}{|c|c|c|c|c|c|c|c|c|c|c|c|c|}
\hline & $J$ & $\mathrm{~F}$ & M & A & M & 1 & 1 & A & S & 0 & $\mathrm{~N}$ & D \\
\hline $\begin{array}{l}1999 \\
2000\end{array}$ & & & & & $\bullet \bullet$ & $\cdots \bullet$ & $\cdots$ & $\bullet \bullet$ & $\ldots$ & $\bullet \bullet$ & $\bullet$ & 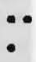 \\
\hline 2001 & - & - & • & $\bullet$ & $\cdots$ & $\bullet$ & $\cdots$ & $\cdots$ & $\ldots$ & $\cdots$ & $\cdots$ & $\bullet$ \\
\hline 2002 & - & - & •. & $\ldots$ & $\bullet$ & 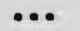 & 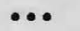 & 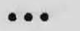 & $\bullet$ & $\ldots$ & $\ldots$ & - \\
\hline 2003 & • & - & $\cdots$ & • & $\cdots$ & $\bullet \bullet$ & $\cdots$ & $\cdots$ & $\cdots$ & $\bullet$ & • & • \\
\hline 2004 & - & & • & - & . & & - & • & • & & & \\
\hline
\end{tabular}

Samplıng was shortened in 2000 (no Secchi measurements; sampling in August 2000 consisted of only seston-sampling).

winter circulation, including the lake bottom, is regularly achieved. The lakes principle water source is the river Ammer, with a mean flow rate of $16.6 \mathrm{~m}^{3} \mathrm{~s}^{-1}$. Consequently, the water residence time is approximately 2.7 years. Due to the large catchment area of the river Ammer the lake collects water from an area of $993 \mathrm{~km}^{2}$. including widely natural and agricultural, but also urban and industrial influenced regions.

Until the late 1970s, the lakc underwent a distinct phase of eutrophication, primarily as a result of increased urbanisation. detergent use and intensification of agriculture in the catchment area, reaching yearly mean total phosphorus concentrations of $60 \mu \mathrm{gl}^{\prime}$. Due to a reduction of anthropogenic influences, the continued eutrophication was halted and reversed, i.e. a reoligotrophication process was initiated. As a consequence, the yearly mean total phosphorus concentrations decreased to approximately $10 \mu \mathrm{g} \mathrm{I}^{-1}$ (Kucklentz et al., 2001).

\subsection{Sample sites and sampling intervals}

Samples and field measurements were generally taken in the middle of the lake $\left(47^{\prime} 58^{\prime}(53.50) \mathrm{N} ; 1107^{\prime}(35.70) E\right)$. Sampling time-points and intervals are depicted in Table 2. Sampling consisted of water sampling for the determination of $P$. rubescens cell densities, measurement of water transparcncy, determination of temperature and oxygen profiles and of monthly seston sampling for the determination of the $P$. rubescens microcystin content. In addition, two seston samples collected previously (in August and November 1998) in an identical manner were included in the sample cohort.

\subsection{P. rubescens abundance}

For the determination of the $P$. rubescens cell densities, water samples $(50 \mathrm{ml}$ ) were taken using a Ruttner flask sampler (Richter \& Wiese, Germany). Samples were taken at $0,3,5,25$ and $40 \mathrm{~m}$ depth. Eight additional metalimnion-specific samples were taken, ranging between 6 and $15 \mathrm{~m}$ depth, always adjusted to the respective metalimnic temperature and thus depth stratification. Water samples were immediately fixed with Lugol's iodine solution and stored in darkness for at least $24 \mathrm{~h}$ until sample filtration. Defined sample volumes were filtered on nitrocellulose membranes (pore size $8 \mu \mathrm{m}$-diameter $25 \mathrm{~mm}$, Schleicher \& Schuell, Germany). Filters were dried in darkness at room temperature and subsequently analysed via fluorescence microscopy and image processing according to the protocol published in Ernst et al. (2006b).

$P$. rubescens biovolumes were estimated for each time-point and sample depth via multiplication of the cell density with the average cross section surface of $25.6 \mu \mathrm{m}^{2}$ as given for $P$. rubescens (Walsby et al., 1998) and a mean cell length of $3 \mu \mathrm{m}$ (Ernst et al., 2006b). Using GraphPad Prism 4 " (USA), the biovolumes obtained were further integrated from the water surface to $40 \mathrm{~m}$ depth to provide for the $P$. rubescens biovolume per $\mathrm{m}^{2}$. Finally, the development of the $P$. rubescens biovolume was compared on a ten-day scale throughout the investigated period (missing timepoints were interpolated from data pre- and post-missing datapoints).

\subsection{Limnological parameters}

Water transparency was determined via a Secchi disk (diameter $25 \mathrm{~cm}$ ) with measurements carried out by the same person throughout the course of the study. Yearly mean values of the Secchi depth $\left({ }^{6} Z_{5}\right)$ were determined via calculation of a timeweighted average, determined during the vegetation period, i.e. from the beginning of May until the end of October each year. No Secchi measurements were carried out in 2000.

The individual euphotic depths $\left(Z_{\mathrm{cu}}\right)$ were estimated from the respective Secchi depths $\left(Z_{\mathrm{s}}\right)$ as $Z_{\mathrm{eu}}=2.5 \times Z_{\mathrm{s}}$ (Lemmin, 1978). Seasonal variations of metalimnic light conditions were estimated using the trends of the euphotic depth measurements throughout the vegetation period.

Temperature, dissolved oxygen and oxygen saturation were determined using a portable oxy-meter (Oxi-197. WTW, Germany). Measurements were performed at intervals of $1 \mathrm{~m}$ starting from the surface to $20 \mathrm{~m}$ depth and in $5 \mathrm{~m}$ intervals starting from 20 to $40 \mathrm{~m}$ depth. The upper limit of the metalimnic layer $\left(Z_{\text {meta }}\right)$ was defined as the depth with a decrease in temperature of $\geq 1 \mathrm{C} \mathrm{m}^{-1}$ and is therefore approximately $1 \mathrm{~m}$ below the mixing zone $\left(Z_{\text {mix }}\right): Z_{\text {meta }}=Z_{\text {mix }}+1$. The seasonal change of the upper metalimnic limit was estimated using the $Z_{\text {meta }}$ determined from the beginning of May until the end of October each year.

In order to characterise the environmental conditions at the depth of $P$. rubescens stratification, the depths of maximum $P$. rubescens cell densities (peak $\mathrm{m}_{\max }$ ) were compared to the Secchi depths $\left(Z_{s}\right)$ and the upper limits of the metalimnic layer $\left(Z_{\text {meta }}\right)$. For this, all measurements from the beginning of May until end of October obtained as of 1999 until 2004 were employed. In addition variations in light conditions and metalimnic stratification were compared within each year and among the years in order to illustrate seasonal and annual differences of metalimnic conditions.

\subsection{Seston sample preparation}

P. rubescens microcystin and phycoerythrin contents were analysed in monthly seston samples (see also Table 2). Samples were taken with a ballasted $40 \mu \mathrm{m}$ gauze net hauled between 5 and $15 \mathrm{~m}$ depth horizontally through the water column. The taxonomical composition of the seston samples was determined via light microscopy using fresh sample aliquots. Classification of cyanobacterial genus was performed in accordance with Anagnostides and Komárek (1988), Suda et al. (2002) and Geitler (1932). The remaining sample volumes were immediately frozen $\left(20^{\circ} \mathrm{C}\right.$ ) and stored until lyophilisation. For analysis, frozen samples were thawed and lyophilised via speed-vac evaporation (Alpha RVC, Christ, Germany), weighed and portioned for methanolic microcystin and aqueous phycoerythrin extraction. 


\subsection{Seston sample microcystin contents}

Seston sample microcystin (MC) contents were determined in order to characterise the variability of microcystin content in $P$. rubescens of Lake Ammersee. As the majority of Planktothrix cells lyse due to freezing and lyophylisation, Planktothrix cell counts were inappropriate as reference for toxin quantification. Thus, $P$. rubescens microcystin content was determined using the phycoerythrin (PE) concentration of the respective seston sample as reference and expressed as MC/PE. Use of phycoerythrin as reference has the advantage of minimizing the interference by zooplankton and algae often reported for chlorophyll and biomass measurements. The use of phycoerythrin as reference additionally minimises the interference due to variations within the seston sample composition since in Lake Ammersee seston samples, high intracellular phycoerythrin concentrations appear to be primarily associated with Planktothrix despite the presence of several other phycoerythrin containing cyanobacteria and of potentially phycoerythrin containing Cryptophyta. Indeed, in comparison to Planktothrix species the latter species contain much lower intracellular phycoerythrin concentrations (Bodemer, 2004), and their abundance in Lake Ammersee was noticeably lower than that of Planktothrix rubescens. Finally, Leboulanger et al. (2002) demonstrated that Planktothrix rubescens can be discriminated from eucaryotic algae and other cyanobacteria species on the basis of fluorescence properties. Therefore, interference in the Lake Ammersee seston phycoerythrin content due to phycoerythrin produced by other phytoplankton is probably negligible.

\subsubsection{Quantification of phycoerythrin}

Phycobilliprotein-concentrations in the lyophilised seston samples were determined via extraction of defined sample quantities ( $\leq 50 \mathrm{mg} \mathrm{dw}$ ) in $1 \mathrm{ml}$ phosphate buffered saline ( $\mathrm{pH}$ $7.0)$ by three freeze-thaw cycles using liquid nitrogen. Each extract was centrifuged ( $45 \mathrm{~min}$ at $40,000 \times \mathrm{g}$ ) and the absorption $(A)$ of the resulting supernatants was determined at wavelengths of 562 , 615 and $652 \mathrm{~nm}$. Absorption was additionally determined at $750 \mathrm{~nm}$ for nullification $(N)$. The optical density for the respective wavelength $\left(O D_{x x x}\right)$ was calculated as $O D_{x x x}=A-N$. Phycocyanin (PC), allophycocyanin (APC) and phycoerythrin (PE) concentrations were calculated according to the description of Tandeau de Marsac (1977) using the following equations:

$\mathrm{PC}\left[\mathrm{mgl}^{-1}\right]=\frac{\left(\mathrm{OD}_{615}-0.747 \times \mathrm{OD}_{652}\right)}{5.34}$
$\mathrm{APC}\left[\mathrm{mgl}^{-1}\right]=\frac{\left(\mathrm{OD}_{652}-0.208 \times \mathrm{OD}_{615}\right)}{5.09}$
$\mathrm{PE}\left[\mathrm{mgl}^{-1}\right]=\frac{\left(\mathrm{OD}_{562}-2.41 \times \mathrm{PC}-0.849 \times \mathrm{APC}\right)}{12.7}$

The extraction procedure was repeated at least three times and the mean phycoerythrin concentration for each seston sample calculated. The analytical protocol provided for a quantification limit of $\leq 0.1 \mu \mathrm{g} \mathrm{PE} \mathrm{mg} \mathrm{l}^{-1} \mathrm{dw}$.

\subsubsection{Quantification of microcystin}

Microcystin was extracted from a defined sample quantity ( $\leq 70 \mathrm{mgdw}$ ) via alternate shaking of the sample suspended in $10 \mathrm{ml}$ of $75 \%$ methanol and ultrasonication at $35 \mathrm{kHz}$ for $1 \mathrm{~h}$. Subsequently the suspension was centrifuged $(10 \mathrm{~min}$ at $10,000 \times g$ ) and the resulting supernatant stored at room temperature while the remaining pellet was re-extracted with $75 \%$ methanol. The extraction procedure was repeated three times for each seston sample and the supernatants were pooled to give one extract for each seston sample.
For further purification and microcystin concentration, sample extracts were reduced to their aqueous component (approximately $7.5 \mathrm{ml}$ ) under a gentle nitrogen stream, replenished to $30 \mathrm{ml}$ with deionised water and applied to preconditioned C-18 end-capped solid phase extraction (SPE) cartridges (mass: $500 \mathrm{mg}$; Isolute ${ }^{\mathrm{k}}$ $C_{18}(E C)$, Germany). Microcystins in the extracts were eluted from the cartridges with $12 \mathrm{ml}$ methanol. Eluents were dried under a gentle nitrogen stream and re-dissolved in $3 \mathrm{ml} \mathrm{20 \%} \mathrm{MeOH}$ for HPLC- and anti-Adda ELISA-analyses (see below).

\subsubsection{HPLC}

HPLC was performed using a Shimadzu (Germany) HPLC equipment (including controller (SCL-10A $\mathrm{VP}$ ), autosampler (SIL $10 A D_{\mathrm{VD}}$ ), two pumps (LC-10AT $\mathrm{VD}$ ), degasser (DGU-14A) and diode array detector (SPD-M10A $\left.A_{V P}\right)$ ), with an analytical $C_{18}$ column (Grom Sil 120 ODS-4 HE, $5 \mu \mathrm{m}, 250 \times 4 \mathrm{~mm}$, Stagroma, Germany). A gradient with water ( $0.05 \%$ TFA) and acetonitrile (0.05\% TFA) was used as the mobile phase according to the method described by Lawton et al. (1994). Microcystin congeners were detected and identified via retention time and typical spectra in comparison with MC-LR, MC-RR, MC-YR, MC-LF, MC-LW standards (all purchased from Alexis, Switzerland), [D-Asp $\left.{ }^{3}\right]-M C-R R$ and [D$\mathrm{Asp}^{3}$ ]-MC-LR (both kindly provided by Prof. Meriluoto, Äbo Akademi University, Turku, Finland) and $\left[\mathrm{Asp}^{3}, \mathrm{Dhb}^{7}\right]-\mathrm{MC}-\mathrm{RR}$ (kindly provided by Dr. J. Blom, University of Zurich, Switzerland). Microcystin concentrations were calculated based on the peak area of the internal MC-LR standard employing a factor of 0.79 for quantification of $\left[\mathrm{Asp}^{3}{ }^{2} \mathrm{Dhb}^{7}\right]-\mathrm{MC}-\mathrm{RR}$ (Hoeger et al., 2007). Based on a detection limit of $10 \mathrm{ng}$ microcystin per injection and an injection volume of $20 \mu \mathrm{l}$, the limit of quantification was estimated at $0.05 \mu \mathrm{g}$ MC-LR equ $\mathrm{mg}^{-1} \mathrm{dw}$.

\subsubsection{ELISA}

The anti-Adda ELISA Kit (Abraxis LLC, USA) is based on an antiserum raised against the unique $C_{20}$ amino acid 3-amino-9methoxy-2,6,8-trimethyl-10-phenyl-4,6-decadieonic acid (Adda), which is common to the majority of known microcystin variants (Fischer et al., 2001). Therefore, Adda-ELISA analyses represent a good approach for the determination of the overall microcystin concentration in the seston samples. The ELISA was performed according to the manufacturer's instructions. Each sample extract was analysed twice using duplicate measurements yielding a mean microcystin content per sample. Due to unspecific matrix-interfering compounds in the highly concentrated seston sample extracts, the limit of quantification (LOQ) was estimated at $0.05 \mu \mathrm{g} \mathrm{mg}^{-1} \mathrm{dw}$.

\subsection{Statistical analyses}

Statistical analyses were carried out using GraphPad Prism $4^{\text {in }}$ (USA) Software. Values are given as mean \pm S.E.M., unless indicated otherwise. The yearly mean values of the Secchi depth $\left({ }^{B} Z_{s}\right)$ were analysed using a two-tailed one-way ANOVA followed correction of multiple analyses using a Bonferroni's post-test.

The depth of maximum P. rubescens cell densities ( peak $_{\text {max }}$ ) was analysed for statistical correlation versus the Secchi depth $\left(Z_{s}\right)$ and the upper limit of the metalimnic layer $\left(Z_{\text {meta }}\right)$ via Pearson's correlation test. Statistical significance of the correlation was determined at the $p<0.05$ level and indicated as ${ }^{* * *} p<0.001$ and ${ }^{*} p<0.05$. Seasonal tendencies in light conditions were estimated via polynomial trends of the euphotic depth $\left(Z_{e u}\right)$ from May until October ( $n=26$ in 1999, $n=17$ in 2001, $n=18$ in 2002 and 2003). No trends were given for 2000 and 2004 due to missing samples or limited sampling intervals $(n=4)$, respectively. The seasonal change in lake stratification was estimated via determination of 
polynomial trends of the upper limit of the metalimnic layer $\left(Z_{\text {meta }}\right)$ determined from May to October ( $n=25$ in 1999, $n=18$ in 2001 . $n=17$ in 2002 and $n=15$ in 2003). No trends were given for 2000 and 2004 due to limited sampling intervals $(n \leq 4)$.

The microcystin congener composition of microcystin-positive Lake Ammersee seston samples as determined via HPLC analyses is given as mean percentage of total microcystin \pm S.E.M. Correlation of the determined MC- and PE-contents were performed using the Pearson's correlation test. Correlation analyses included all microcystin-positive samples acquired from August 1998 to September 2004 and were performed for HPLC- and ELISA-determinations independently. Statistical significance of the correlation was determined at the $p<0.05$ level and indicated as ${ }^{* * *} p<0.001$. MC/PE ratios were analysed for outliers using the Tukey box plot rule.
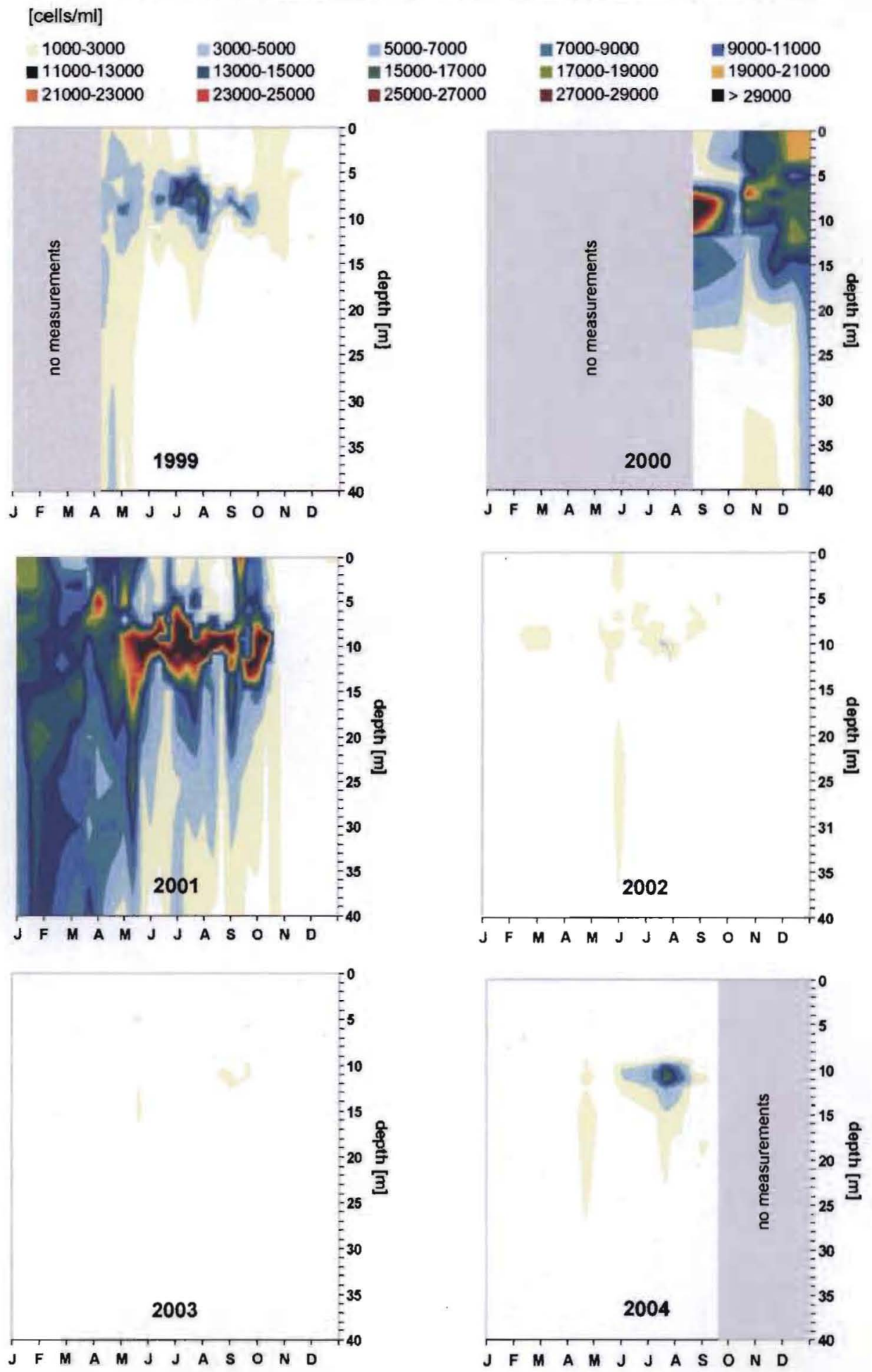

Fig. 1. The spatial and seasonal abundance of $P$. rubescens in the upper $40 \mathrm{~m}$ of Lake Ammersee from 1999 to 2004. 
Table 3

Summary of periods displaying P. nubescens cell densities which have experimentally been shown to affect exposed coregonids (Ernst er al., 2007), and the time-weighted, yearly mean values of the Secchi depths $\left({ }^{\circledR} Z_{s}\right)$ determined during the vegetation period, i.e. from the beginning of May until end of October for each year

\begin{tabular}{|c|c|c|c|c|}
\hline & \multicolumn{3}{|c|}{ P. rubescens (cells/mil) } & \multirow[t]{2}{*}{${ }^{n} Z_{s}(m)$} \\
\hline & $\geq 55,000$ & $\geq 15,000$ & $\geq 1500$ & \\
\hline $\begin{array}{l}1999^{h} \\
2001^{b}\end{array}$ & $\overline{\text { July-August }}$ & $\begin{array}{l}\text { July } \\
\text { August-September, October-December" }\end{array}$ & $\begin{array}{l}\text { April-October } \\
\text { August-December" }\end{array}$ & $3.3 \pm 0.19$ \\
\hline 2001 & - & January. March-October ${ }^{-1}$ & January-October' & $3.3 \pm 0.34$ \\
\hline 2002 & - & - & May-September & $2.7 \pm 0.21$ \\
\hline 2003 & - & - & August-September & $2.9 \pm 0.26$ \\
\hline $2004^{\circ}$ & - & July & June-September & $3.6 \pm 0.15$ \\
\hline
\end{tabular}

Z values are given as mean \pm S.E.M. ( $\pi \geq 15$ ). No Secchi measurements were carried out in 2000

Distributed nver the entire water column.

1. Measurements were not performed throughout the whole year.

\section{Results}

\subsection{P. rubescens abundance}

During the 261-week observation period, starting in April 1999 and ending September 2004, P. rubescens was always present, albeit at varying cell densities. The distribution patterns observed included phases with a distribution over the entire $40 \mathrm{~m}$ water column investigated, as well as phases with distinct metalimnic layers (Fig. 1). Maximum cell densities during winter circulation, whereby $P$. rubescens was mostly distributed throughout the entire water column, reached 15,000 cells $\mathrm{ml}^{-1}$. Maximum $P$. rubescens cell densities in the metalimnic layer reached 77.000 cells $\mathrm{ml}^{-1}$ and 45,000 cells $\mathrm{ml}^{-1}$ as observed in $8-10 \mathrm{~m}$ depth in the end of August 2001 and 2000, respectively. $P$. rubescens cell densities of $\geq 55,000$ cells ml ${ }^{-1}$ occurred during 6 weeks, densities of $\geq 15,000$ cells ml ' during 53 weeks, and densities of $\geq 1500$ cells $\mathrm{ml}^{-1}$ during 123 weeks, corresponding $2 \%, 22 \%$ and $47 \%$ of the 261-week observation period, respectively (Table 3 ). Integrated $P$. rubescens biovolumes are summarised in Fig. 2. Maximum biovolumes were observed at the onset of lake stratification in May 2001, reaching $45 \mathrm{~cm}^{3} \mathrm{~m}^{2}$.

Yearly onset of lake thermal stratification was recurrent between 20th of April and the 10th of May. Layers of $P$. rubescens filaments were regularly observed as of the beginning of thermal lake stratification (Fig. 1). During stratification, the depth of maximum $P$. rubescens cell densities (peak ${ }_{\text {inax }}$ ) ranged between 7 and $13 \mathrm{~m}$ depth and significantly correlated with the Secchi depth and the upper limit of the metalimnic layer (Fig. 3).

The time-weighted, yearly mean values of the Secchi depths $\left({ }^{\oplus} Z_{s}\right)$ are depicted in Table 3. Although differences in ${ }^{\varnothing} Z_{s}$ were not statistically significant, metalimnic conditions differed from May to October as well as from year to year. There were vegetation periods with a high water transparency and sustained euphotic depths reaching the upper limit of the metalimnic layer (i.e. 1999, 2001 and 2004), as shown in Fig. 4. However, there were also vegetation periods, where the euphotic depths did not or only temporarily reach the upper limit of the metalimnic layer (i.e. 2002 and 2003). With the exception of 1999, the seasonal development of Lake Ammersee thermal stratification was roughly identical throughout the observation period. However, there were marked differences regarding water transparency and respective extent of the euphotic depth (Fig. 5).

\subsection{Seston sample phycoerythrin and microcystin contents}

Phycoerythrin (PE) was detectable in all Lake Ammersee seston samples. The overall mean seston PE-content was $3.4 \pm 0.7 \mu \mathrm{g}$ PE mg ${ }^{-1} \mathrm{dw}(n=54)$. Microcystins (MC) were detectable in 27 and 38 of 54 seston samples via HPLC and Adda-ELISA measurements, respectively.

In all of the 27 Lake Ammersee seston samples that were microcystin-positive, as determined via HPLC analyses, the main microcystin congener ( $79 \pm 4 \%$ of the total microcystin) had a retention time and spectrum consistent with $\left[\right.$ Asp $\left.^{3}\right]-M C-R R$. Seventeen samples contained a microcystin variant with a retention time and spectrum consistent with $\left[\mathrm{Asp}^{3} \mathrm{Dhb}^{7}\right]-\mathrm{MC}-\mathrm{RR}$ ( $14 \pm 1 \%$ of the total microcystin). Twenty two samples contained a microcystin variant with a retention time and spectrum consistent with $\left[\mathrm{Asp}^{3}\right]$ MC-LR $(9+2 \%$ of the total microcystin), and 18 samples contained a further MC-RR-variant with a retention time which was not comparable to the employed internal standards, however presenting with a spectrum characteristic for microcystin congeners $(8+2 \%$ of the total microcystin) (Fig. 6).

Irrespective of the analytical method, the detected microcystin amounts significantly correlated with the PE-contents determined (Fig. 7). MC/PE ratios are summarised in Table 4 . The variation in $\mathrm{MC} / \mathrm{PE}$ ratios throughout the six-year observation period was low, with statistical outliers only in May and December 1999 (for both HPLC and ELISA analyses), and in June and August 1999 and August 2000 (for ELISA analyses only). The mean of the determined seston microcystin contents was $0.21 \pm 0.03 \mu \mathrm{g} \mathrm{MC}-\mathrm{LR}_{\text {equ }} \mu \mathrm{g}^{-1} \mathrm{PE}(n=27)$ via HPLC- and $0.43 \pm 0.06 \mu \mathrm{g} \mathrm{MC-LR}$ equ $\mu g^{-1} \mathrm{PE}(n=38)$ via ELISA determination, corresponding $0.85 \pm 0.11 \mu \mathrm{g} M C-\mathrm{LR}_{\text {equ }} \mathrm{mg}^{-1} \mathrm{dw}$ $(n=27)$ and $1.50 \pm 0.22 \mu \mathrm{g} \mathrm{MC}-\mathrm{LR}_{\text {equ }} \mathrm{mg}^{-1} \mathrm{dw}(n=38)$, respectively.

\subsection{Oxygen}

The water column was saturated with oxygen as of the beginning of circulation usually starting at the end of November ( $t=2-3$ weeks) and attaining full circulation by the end of December (Fig. 8). With the beginning of lake stratification in May, the epilimnion (corresp. approximately $0-8 \mathrm{~m}$ depth) was often supersaturated (e.g. $120 \%$ saturation; data not shown), occasionally reaching maximum levels of $150 \%$ saturation (August 2001). Subsequently and simultaneous with prolonged lake stratification and a sustained shift of the thermocline into deeper layers, oxygen measurements suggested decreasing oxygen saturation in the metalimnion (as of June in 2002 and July in 1999, 2001, 2003 and 2004). Metalimnic oxygen values regularly were minimal at the end of September and in October, i.e. $3.7 \mathrm{mg} \mathrm{I}^{-1}$ in $1999,4.0 \mathrm{mg} \mathrm{I}^{-1}$ in $2001,5.1 \mathrm{mg} \mathrm{l}^{-1}$ in 2002 , and $4.6 \mathrm{mg} \mathrm{l}^{-1}$ in 2003.

\section{Discussion}

\subsection{P. rubescens distribution and succession}

Comparable to $P$. rubescens occurrences observed in deep prealpine lakes in Italy (Salmaso, 2000; Buzzi, 2002; Morabito et al., 

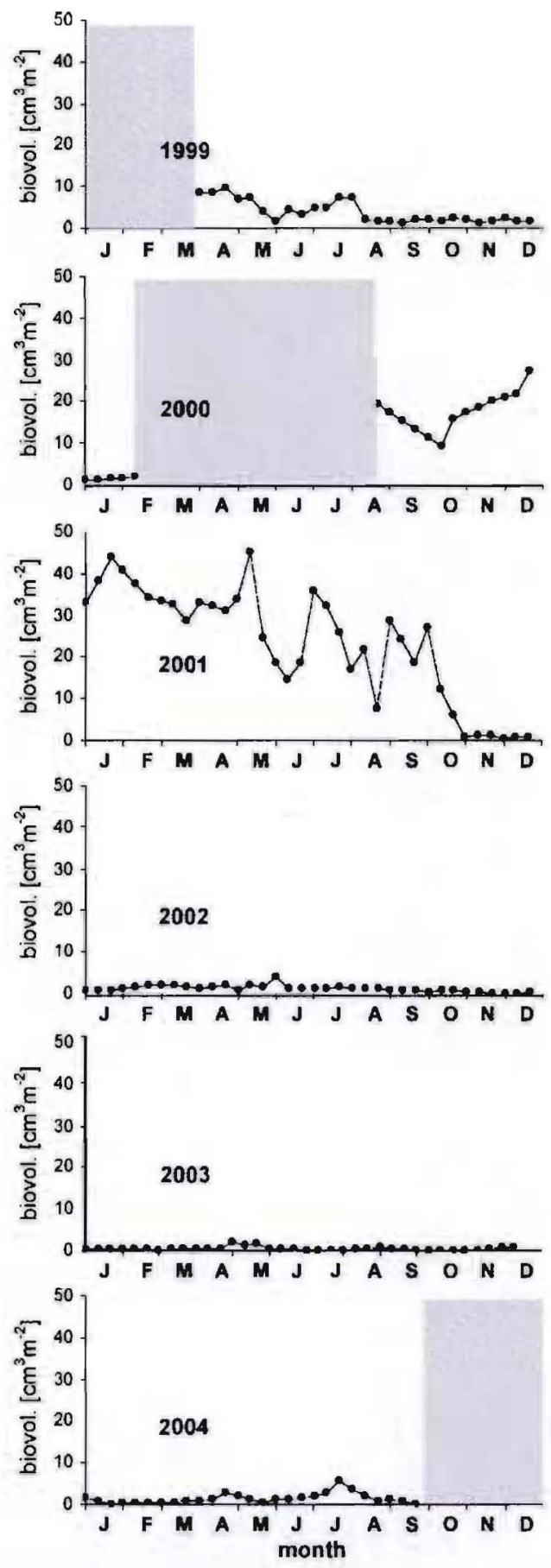

Periods without regular sampling are shaded

Fig. 2. Integrals of the $P$. rubescens biovolume in Lake Ammersee, as determined from the surface to $40 \mathrm{~m}$ depth.

2002; Legnani et al., 2005), Switzerland (Walsby et al., 1998) and France (Jacquet et al., 2005) the $P$. rubescens assemblage in Lake Ammersee appears to proceed in a uniform annual pattern. As demonstrated by Walsby et al. (1998), P. rubescens cells can remain viable during winter mixing down to $80 \mathrm{~m}$ depth. Considering the maximum depth of $82 \mathrm{~m}$, the $P$. rubescens population in Lake Ammersee thus obviously can endure winter circulation. This is confirmed by the constantly high integrated $P$. rubescens biovo- lume during mixing in winter 2000/2001. The winter endurance of the $P$. rubescens population may provide $P$. rubescens with an early competitive advantage in exploiting the resources available at the beginning of the vegetation period (Walsby et al., 1998; Legnani et al., 2005). Despite this, a regular short-term decline in $P$. rubescens abundance is observed during early spring in Lake Ammersee, as is also observed in other lakes (Waisby et al., 1998; Bettinetti et al., 2000; Salmaso, 2000; Walsby and Schanz, 2002). The latter is assumed to stem from the change in hydrostatic conditions. As shown by Walsby et al. (1998), the beginning of lake stratification provides a natural selection for $P$. rubescens cells with strong gas vesicles, enabling filaments to remain buoyant after winter mixing and consequently remain able to stratify in the water column. Filaments that float to the surface mixed layer or remain within the hypolimnion disappear at the beginning of lake stratification, most likely due to high UV irradiance and nutritional competition in the surface layer and cold temperature as well as light limitation in the hypolimnion (Mur et al., 1999; Walsby and Schanz, 2002).

Maximum $P$. rubescens cell densities are observed in Lake Ammersee, as in other lakes, within compact stratified layers as of late spring (Walsby and Schanz, 2002; Jacquet et al., 2005; Blikstad-Halstvedt et al., 2007). As indicated by the correlation of peak ${ }_{\text {max }}$ and $Z_{\text {meta }}\left(Z_{\text {meta }}=0.45 \times\right.$ peak $\left._{\max }+3.3\right)$, the $P$. rubescens peaks - regularly located at $7-13 \mathrm{~m}$ depth - are situated approximately $0.5-4 \mathrm{~m}$ below the upper limit of the metalimnion, thus closely related to the strong thermal gradient stabilizing the stratified water column. Moreover, the depth of $P$. rubescens stratification broadly corresponds (for peaks in 7-13 m) with the triple of the Secchi depths (peak $k_{\max } \approx 3 \times Z_{s}$ ), as demonstrated by the correlation of peak $\mathrm{max}_{\max }$ and $Z_{\mathrm{S}}\left(Z_{\mathrm{s}}=0.11 \times\right.$ peak $\left._{\max }+2.1\right)$. Thus the depth of $P$. rubescens stratification is slightly below the standard estimation for the euphotic depth $\left(Z_{\mathrm{eu}}=2.5 \times Z_{\mathrm{s}}\right.$, Lemmin, 1978), albeit in accordance with the approximation given by Dokulil and Teubner (2000) and euphotic depths recently estimated in other meso- and oligotrophic lakes (Salmaso, 2000; Buzzi, 2002; Morabito et al., 2002).

The light intensity at the observed $P$. rubescens stratification depth probably corresponds to $\geq 1 \%$ of the surface irradiance, which is suggested to be sufficient for the low light requirements of P. rubescens (Mur et al., 1999). The latter data thus confirm that the border between epilimnion and metalimnion represents an ecological niche that prevents $P$. rubescens filaments from mixing within the surface layer while simultaneously providing sufficient light for $P$. rubescens growth (Micheletti et al., 1998; Walsby et al., 1998; Morabito et al., 2002). The decrease of the thermal gradient due to cooling of the surface following lower daytime temperatures and convective cooling during night in autumn - provides for an increased mixing of the near-surface layers, which may include near metalimnic layers (Walsby et al., 1998; Salmaso, 2000; Buzzi, 2002; Teubner et al., 2004; Blikstad-Halstvedt et al., 2007). Consequently, $P$. rubescens filaments may be mixed within the surface layer, where they can accumulate and provide for the surface blooms occasionally observed in stratified lakes (Walsby et al., 1998; Walsby and Schanz, 2002; Blikstad-Halstvedt et al., 2007).

\subsection{P. rubescens cell densities and biovolumes}

P. rubescens occurred in Lake Ammersee continuously, throughout the observation period of six years, as shown via $P$. rubescens cell counts and presence of detectable phycoerythrin. Cell densities and integrated biovolumes were in the range of those previously observed in other pre-alpine lakes, irrespective of whether they were determined during winter circulation or summer stratifica- 

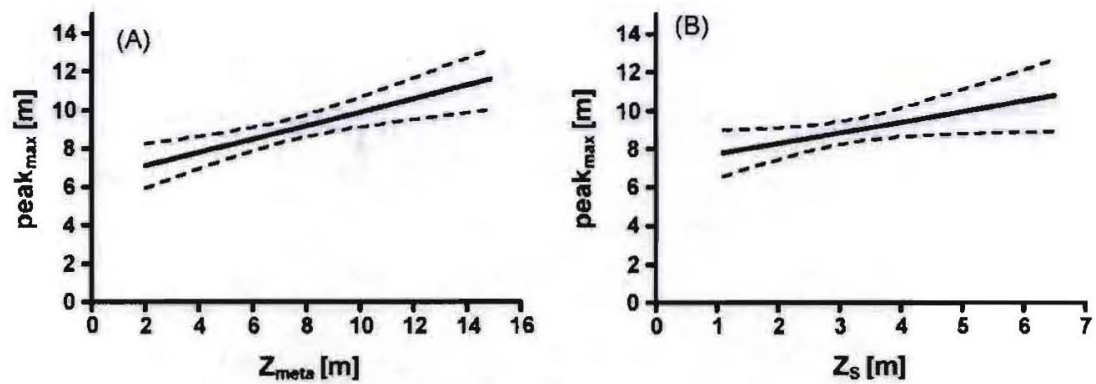

Fig. 3. Correlation ( $\pm 95 \%$ confidence interval of the mean) of the depth of maximum $P$. rubescens densities (peak $k_{\text {max }}$ ) to $(A)$ the upper metalimnic limit $\left(Z_{\text {meta }}\right)$ and $(B)$ the Secchi depth $\left(Z_{s}\right)$. Correlation was statistically significant (Pearson's correlation test) for $Z_{\text {mera }}(n=72, r=0.40, p<0.001)$ as well as for $Z_{\varsigma}(n=71, r=0.25, p<0.05$ ).
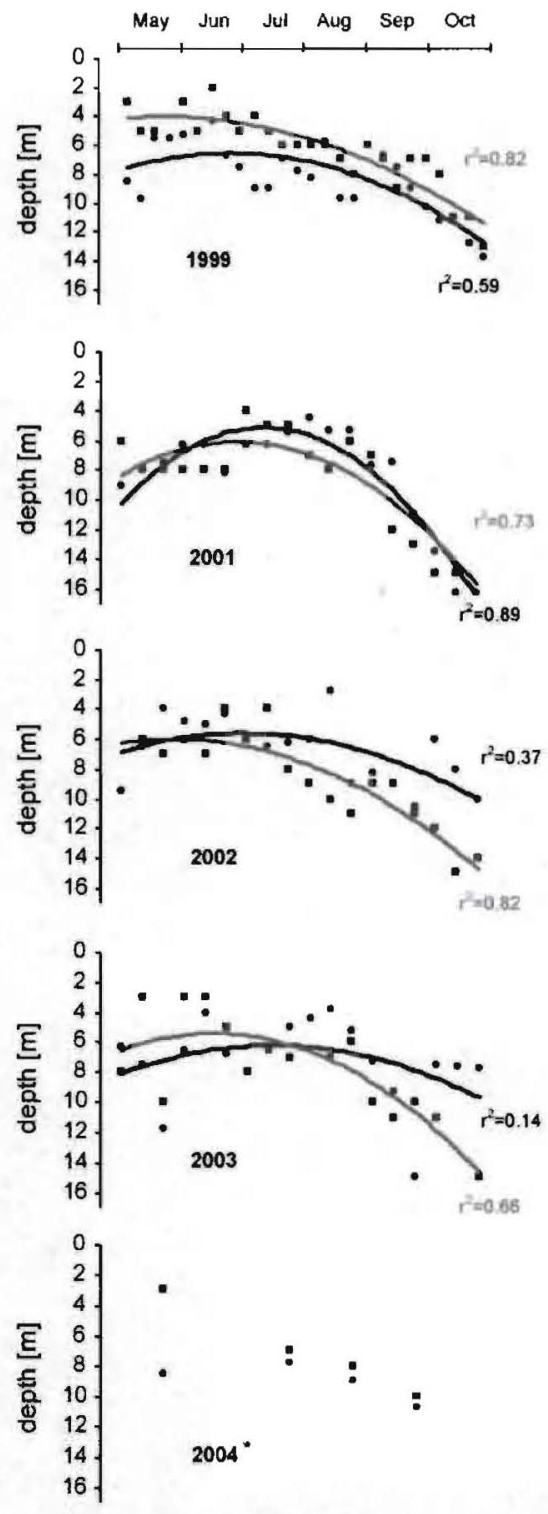

* Trends were not estimated due to deficient sample intervals

Fig. 4. Spatial and seasonal development of the euphotic depth $Z_{\mathrm{eu}}$ (black) and the upper metalimnic limit $Z_{\text {meta }}$ (grey) in Lake Ammersee (depicted as polynomial trends) from the beginning of May until end of October (periods of vegetation) in 1999, 2001, 2002, 2003 and 2004. tion (Walsby and Schanz, 2002; Hoeger et al., 2005; Jacquet et al., 2005).

Spatial differences in $P$. rubescens abundance within Lake Ammersee appear to be minimal and to occur only temporarily as suggested by sporadic sampling at a second sampling point in the north of the lake (Ernst et al., unpublished data). In contrast, regarding both maximum cell densities and the integrated $P$. rubescens biovolume, considerable differences in $P$. rubescens abundances were observed between different years. Based on the cell densities and integrated biovolumes, the highest $P$. rubescens abundance was observed in 2001 followed by $2000>1999>2004>2002,2003$. This raises the question which factors influence these apparent differences in annual $P$. rubescens abundance.

Obviously. P. rubescens growth in deep pre-alpine lakes is likely to be affected by multiple factors and/or processes (Dokulil and Teubner, 2000; Walsby and Schanz, 2002; Jacquet et al., 2005; Blikstad-Halstvedt et al., 2007, etc.) including nutrient conditions. As nutrient concentrations were not part of the current investigation, the discussion on the influence of the nutritional conditions remains largely hypothetical. However, $P$. rubescens dominates the phytoplankton biomass in stratified, re-oligotrophicated lakes frequently at total phosphorus-concentrations of approximately $10 \mu \mathrm{g} \mathrm{I}^{-1}$ (Dokulil and Teubner, 2000; Salmaso, 2000; Morabito et al., 2002). This applies to Lake Ammersee, where the mean annual total phosphorus concentration never exceeded $15 \mathrm{\mu g} \mathrm{l}^{-1}$ during the past decade (Teubner et al., 2004). In re-oligotrophicated lakes with $<15 \mu \mathrm{g}$ total phosphorus-concentration per litre, phosphate depletion strongly influences seasonal phytoplankton succession in the epilimnion in the course of a year (Anneville et al., 2002). Indeed, Jacquet et al. (2005) observed $P$. rubescens mass occurrence to arise when phosphate had severely been depleted in Lake Bourget, France. This appears possible due to the ability of $P$. rubescens to grow at the border of the euphotic zone allowing it to benefit from the nutrient rich metalimnion (Anneville et al., 2002; Walsby and Schanz, 2002). Moreover, $P$. rubescens, which is capable of excreting alkaline phosphatases into the ambient water, has the physiological advantage of utilizing organic phosphorus when inorganic phosphates are growth limiting (Feuillade, 1994). Indeed growth limitation for phytoplankton species other than $P$. rubescens will also reduce the degree of shading in the surface mixed layer, therefore providing for sufficient illumination in deeper zones, as discussed below (Bürgi and Stadelınann, 2002; Walsby and Schanz, 2002; Legnani et al., 2005).

Blikstad-Halstvedt et al. (2007) observed that the nutritional conditions determined in Lake Steinsfjorden, Norway, were often below the minimum $\mathrm{N}$ and $\mathrm{P}$ levels which allowed maximum $P$. rubescens growth rate in culture studies. This applied to both, the epi- and metalimnion, particularly with regard to nitrogen levels. Thus, $P$. rubescens populations may thrive under high nitrogen 

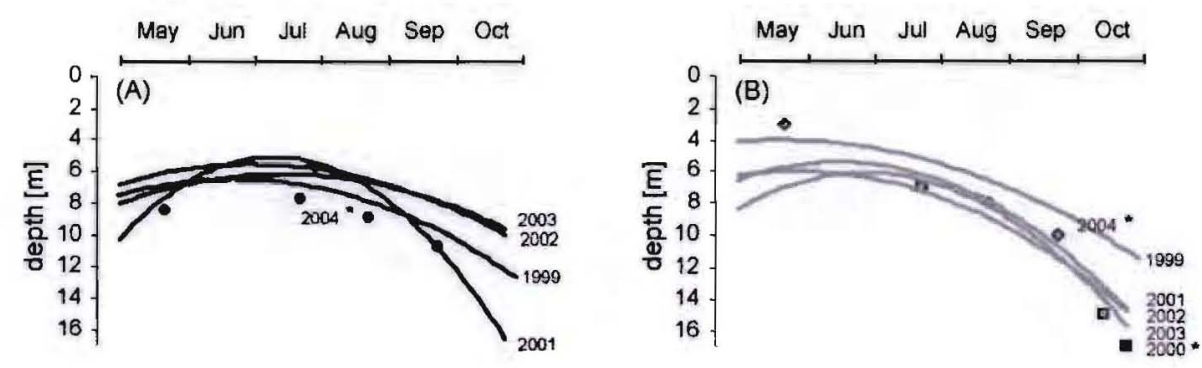

* Trends were not estimated due to deficient sample intervals

Fig. 5. Comparison of the spatial and seasonal development of the euphotic depth $Z_{\text {eu }}$ (A) and the upper metalimnic limit $Z_{\text {mets }}$ (B) in Lake Ammersee (depicted as polynomial trends) during the periods of vegetation (beginning of May until end of October) in 1999, 2001, 2002, 2003 and 2004.

concentrations. This interpretation is supported by the observation that $P$. rubescens mass occurrence primarily arises in lakes with low phosphate and high nitrogen loads as observed in many oligoand mesotrophic pre-alpine lakes (Salmaso, 2000; Zotina et al., 2003: Teubner et al., 2004; Jacquet et al., 2005), including Lake Ammersee, where mean nitrogen concentrations regularly exceed $1 \mathrm{mg} \mathrm{l}^{-1}$ (Nixdorf et al., 2004).

Another important factor influencing $P$. rubescens growth appears to concern the temperature regime (Blikstad-Halstvedt et al., 2007). Jacquet et al. (2005) suggested that a possible reason for the increasing success of $P$. rubescens may be an earlier onset of lake stratification and thus longer water column stratification in lakes due to global warming. However, it is unlikely that the annual variation in $P$. rubescens abundance observed in Lake Ammersee was caused by differences in the thermal stratification, especially as the onset of lake thermal stratification was comparable throughout the investigation period. In addition, the latitude of the mixed surface layer and the temporal development of the thermal stratification were roughly identical throughout the study $\left(Z_{\text {meta }}\right.$ exceeded the long-standing average only in 1999 , which can without doubt be ascribed to an extreme flood, which raised the water level by approximately $2 \mathrm{~m}$; www.hnd.bayern.de). However, the suggestion by Jacquet et al. (2005) cannot be totally dismissed as decisively longer observation periods would be required to definitively assign global warming induced small changes in onset of lake temperature stratification to $P$. rubescens abundance.

The observation that time-weighted yearly mean values of the Secchi depths $\left({ }^{\circ} Z_{\mathrm{s}}\right)$ were $>3 \mathrm{~m}$ in 1999, 2001 and 2004 and contrastingly $<3 \mathrm{~m}$ in 2002 and 2003 however, suggests that $P$. rubescens growth might primarily be related to differences in water transparency and therefore to light conditions. Indeed, the comparison of the annual $P$. rubescens abundances with the respective seasonal trend of the upper metalimnic limit $\left(Z_{\text {meta }}\right)$ and the latitude of the euphotic depth demonstrated that $P$. rubescens abundance was high, when the vegetation periods were characterised by high water transparency and sustained euphotic

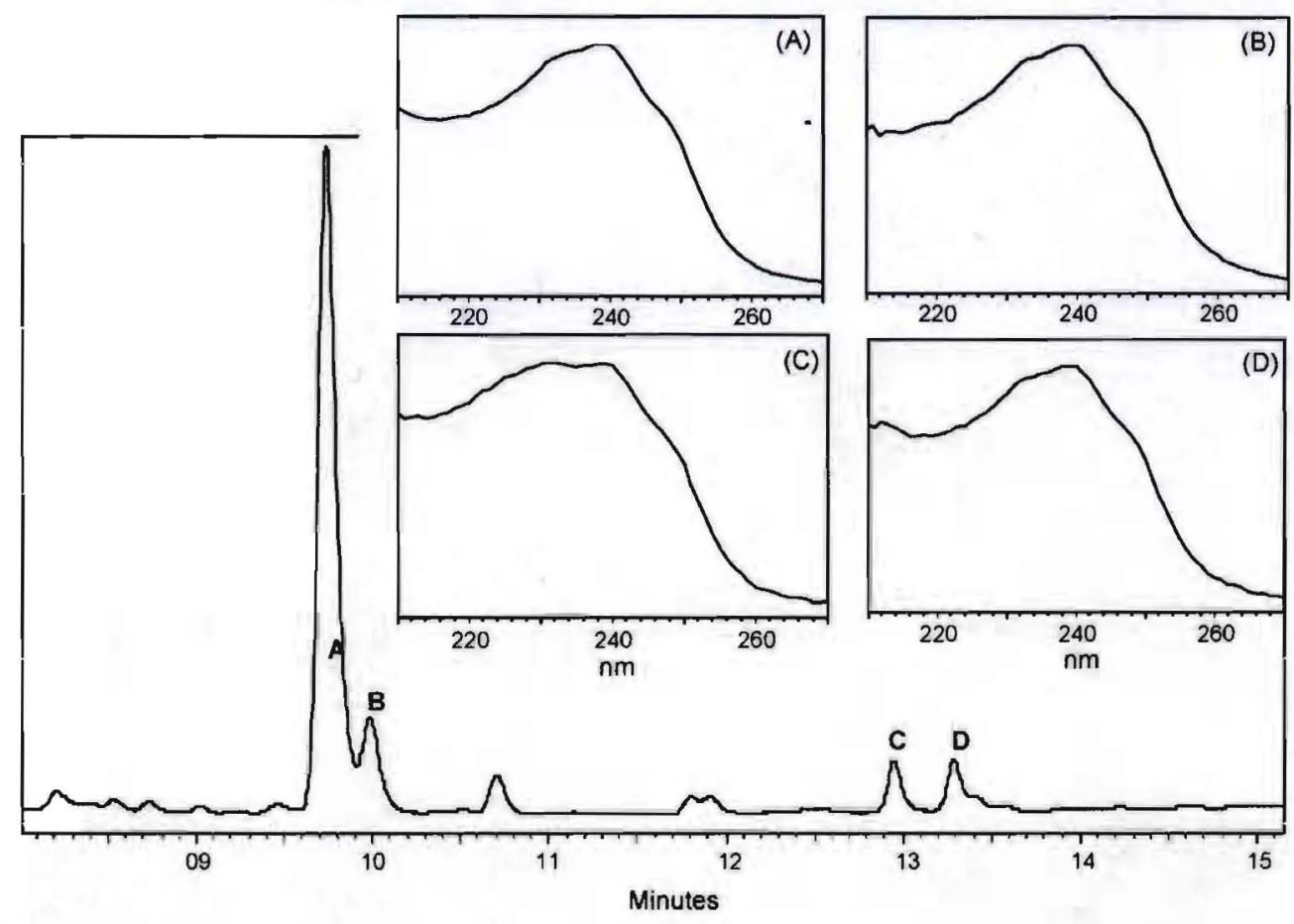

Fig. 6. HPLC-chromatogram of a Lake Ammersee seston sample (November 2000) with four MC-variants and respective retention times and spectra consistent with [Asp ]MC-RR (A). [Asp $\left.{ }^{3} \mathrm{Dhb}^{7}\right]-\mathrm{MC}-\mathrm{RR}(\mathrm{B})$ and $\left[\mathrm{Asp}^{3}\right]-\mathrm{MC}-\mathrm{LR}(\mathrm{D})$. The fourth spectrum (C) being comparable to those characterised for MC-congeners is proposed to represent another MC-RR variant. 

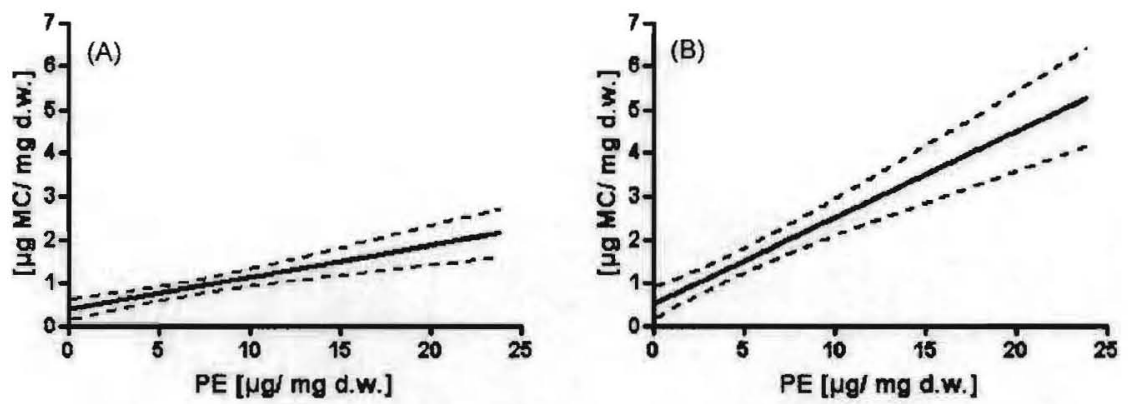

Fig. 7. Correlation ( $+95 \%$ confidence interval of the mean) of the microcystin (MC)-content with the phycoerythrin (PE)-content in Lake Ammersee seston samples. MC-analyses were performed using (A) HPLC and (B) ELISA analyses. Correlation was statistically significant (Person's correlation test) for both HPLC ( $n=27, r=0.70, p<0.001$ ) and ELISA analyses $(n=38, r=0.74, p<0.001)$.

depths reaching the upper limit of the metalimnic layer (i.e. 1999, 2001 and 2004). In contrast, P. rubescens abundance was low, when the euphotic depths did not or only temporarily reached the upper limit of the metalimnic layer (i.e. 2002 and 2003). Moreover, the development of the thermal stratification was comparable throughout the observation period, further corroborating the hypothesis that $P$. rubescens abundance in Lake Ammersee is primarily affected by water transparency and $Z_{\text {eu }} / Z_{\text {mix }}$-ratios $\geq 1$ (whereby $Z_{\text {mix }}$ is the latitude of the mixed surface layer $\left(Z_{\text {mix }}=Z_{\text {meta }}-1\right)$. Indeed, Mur and Schreurs (1995) noted that stratifying Planktothrix species usually grow in water columns with $Z_{\text {eu }} / Z_{\text {mix }}$ ratios close to $0.7-1.2$. An increased average $Z_{\text {eu }} / Z_{\text {mix }}$ ratio to $0.9-1$ is also discussed as a key to the success of $P$. rubescens in Lake Bourget, France (Jacquet et al., 2005). The importance of light conditions for $P$. rubescens growth is also supported by findings of Dokulil and Teubner (2000), showing that dominance of stratifying $P$. rubescens in Lake Mondsee, Austria, is associated with light climate correlatives $\left(Z_{\mathrm{mix}} / Z_{\mathrm{s}}\right)$ of approximately 4 (Dokulil and Teubner, 2000), which corresponds $Z_{\mathrm{eu}} / Z_{\mathrm{mux}}$ ratios of $\geq 0.7$, largely depending on the $Z_{\text {eu }}$-approximation used.

\subsection{P. rubescens microcystin contents}

The average microcystin content in microcystin-positive seston samples in this study was $0.85 \pm 0.11 \mu \mathrm{g} \mathrm{MC}^{-L_{\text {equ }}} \mathrm{mg}^{-1}$ $\mathrm{dw}$ via HPLC and $1.50 \pm 0.22 \mu \mathrm{g} M C-\mathrm{LR}_{\text {equ }} \mathrm{mg}^{-1} \mathrm{dw}$ via ELISA determination. This is within the range of microcystin contents previously determined in $P$. rubescens extracts and seston sample extracts of $P$. rubescens dominated lakes (Fastner et al., 1999a; JannPara et al., 2004; Kurmayer et al., 2005). The results obtained in Lake Ammersee thus confirm that Planktothrix species contain comparably high amounts of microcystin (Fastner et al., 1999a; Akcaalan et al., 2006).

The HPLC-analyses demonstrated that $P$. rubescens in Lake Ammersee primarily produce one main microcystin congener, i.e. [Asp ${ }^{3}$ ]-MC-RR, far lower concentrations of two additional microcystin congeners, i.e. $\left[\mathrm{Asp}^{3}, \mathrm{Dhb}^{7}\right]-\mathrm{MC}-\mathrm{RR}$ and $\left[\mathrm{Asp}^{3}\right]-\mathrm{MC}-\mathrm{LR}$, and one putative uncharacterised microcystin variant. This observation concurs with previous studies, describing demethylated variants of MC-RR to be the predominant microcystin congeners of $P$. rubescens (Luukkainen et al., 1993; Fastner et al., 1999a; Blom et al., 2001; Kurmayer et al., 2005), accompanied by a varying number of characterised microcystin variants such as [Asp $\left.{ }^{3}\right]-\mathrm{MC}$ LR, $\left[\right.$ Asp $\left.^{3}\right]-M C-H t y R$ and $\left[A \mathrm{As}^{3}\right]-\mathrm{MC}-\mathrm{YR}$, and as yet uncharacterised congeners (Fastner et al., 1999a; Grach-Pogrebinsky et al., 2003; Kurmayer et al., 2005). It is thus not surprising that differences were observed between microcystin determination via ELISA and HPLC. Indeed, HPLC analysis of microcystins is entirely dependent on the availability of standards, whereas the Adda-ELISA recog-
Table 4

Microcystin contents and potentially toxic cyanobacterial species present in Lake Ammersee seston samples collected from August 1998 until September 2004

\begin{tabular}{|c|c|c|c|}
\hline & \multicolumn{2}{|c|}{$\left\langle\mu g \mathbf{M C}_{\text {equiv }} / \mu \mathrm{g}\right.$ PE) } & \multirow[t]{2}{*}{ Abundant species } \\
\hline & HPLC & ELISA & \\
\hline \multicolumn{4}{|l|}{1998} \\
\hline August & 0.2 & 0.2 & Ptx \\
\hline November & 0.2 & 0.7 & Ptx \\
\hline \multicolumn{4}{|l|}{1999} \\
\hline April & 0.1 & 0.2 & $\mathbf{P t x}$ \\
\hline May & 0.8 & 1.2 & $\mathrm{Ptx}$ \\
\hline June & 0.3 & 1.2 & Ptx \\
\hline July & 0.3 & 0.5 & Ptx \\
\hline August & 0.3 & 1.1 & $\mathrm{Ptx}$ \\
\hline September & 0.1 & 0.4 & $\mathrm{Ptx}$ \\
\hline Octaber & 0.3 & 0.7 & Ptx \\
\hline November & 0.2 & 0.6 & Ptx \\
\hline December & 0.7 & 1.9 & $\mathrm{PEx}$ \\
\hline \multicolumn{4}{|l|}{2000} \\
\hline August & 0.4 & 1.1 & Ptx \\
\hline October & 0.2 & 0.5 & Ptx \\
\hline November & 0.3 & 0.5 & Ptx \\
\hline December & 0.1 & 0.2 & Ptx \\
\hline \multicolumn{4}{|l|}{2001} \\
\hline Jamuary & 0.1 & 0.3 & Ptx \\
\hline February & 0.2 & 0.4 & $\mathrm{Ptx}$ \\
\hline March & 0.1 & 0.1 & Ptx \\
\hline April & 0.1 & 0.3 & Ptx \\
\hline May & 0.1 & 0.2 & $\mathbf{P t x}$ \\
\hline June & 0.1 & 0.3 & $\mathbf{P t x}$ \\
\hline July & 0.1 & 0.4 & Ptx \\
\hline August & 0.1 & 0.2 & Ptx \\
\hline September & 0.1 & 0.3 & Ptx \\
\hline Dctaber & n.d. & 0.4 & Ptx \\
\hline November & $\cdot$ & $\cdot$ & $P t x$ \\
\hline December & * & • & $P+x$ \\
\hline \multicolumn{4}{|l|}{2002} \\
\hline January & $\cdot$ & • & Ptx \\
\hline February & n.d. & n.d. & $P t x$ \\
\hline March & n.d. & n.d. & Ptx \\
\hline April & n.d. & n.d. & Ptx \\
\hline May & n.d. & 0.3 & Ptx \\
\hline June & 0.1 & 0.3 & $\operatorname{Ptx}$ \\
\hline July & 0.1 & 0.2 & Ptx \\
\hline August & n.d. & 0.3 & PDx, Mic, Ana \\
\hline September & n.d. & n.d. & Ptx, Mic, Ana \\
\hline October & n.d. & n.d. & Ptx, Mic, Ana \\
\hline November & n.d. & n.d. & Ptx \\
\hline December & n.d. & n.d. & $\mathrm{Ptx}$ \\
\hline \multicolumn{4}{|l|}{2003} \\
\hline January & n.d. & n.d. & $P t x$ \\
\hline February & n.d. & n.d. & Ptx \\
\hline March & n.d. & n.d. & Ptx \\
\hline April & n.d. & n.d. & $P t x$ \\
\hline
\end{tabular}


Table 4 (Continued)

\begin{tabular}{|c|c|c|c|}
\hline & \multicolumn{2}{|c|}{$\left(\mu \mathrm{g} \mathrm{MC}_{\text {equiv }} / \mu \mathrm{g} \mathrm{PE}\right)$} & \multirow[t]{2}{*}{ Abundant species } \\
\hline & HPLC & ELISA & \\
\hline May & n.d. & 0.2 & PQx \\
\hline June & n.d. & n.d. & Ptx \\
\hline July & n.d. & n.d. & $\mathrm{Ptx}$ \\
\hline August & n.d. & 0.1 & Pox, Mic, And \\
\hline September & n.d. & 0.1 & Ptx, Mic, Ana \\
\hline October & n.d. & 0.1 & Ptx, Mic, Ana \\
\hline November & n.d. & n.d. & Ptx \\
\hline December & n.d. & 0.2 & Ptx \\
\hline \multicolumn{4}{|l|}{2004} \\
\hline January & n.d. & 0.1 & Ptx \\
\hline March & n.d. & n.d. & Ptx \\
\hline April & n.d. & n.d. & PEx \\
\hline May & - & $\cdot$ & Ptx \\
\hline July & 0.1 & 0.3 & $P t x$ \\
\hline August & n.d. & 0.1 & Ptx, Mic, Ana \\
\hline September & n.d. & 0.1 & Ptx, Mic, Ana \\
\hline
\end{tabular}

Microcystin-amounts were analysed via HPLC and ELISA and expressed as

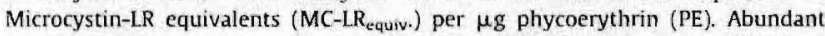
cyanobacterial species were Planktothrix rubescens (Ptx), Microcystis $\mathrm{sp}$. (Mic) and Anabaena sp. (Ana). Cyanobacteria marked in bold represented a main component of the phytoplankton community. n.d: not detectable (<quant. limit). "Deficient sample volumes.

nises nearly all microcystin congeners with comparable sensitivity. Nevertheless, microcystins were detectable in $50 \%$ and $70 \%$ of the investigated seston samples via HPLC and Adda-ELISA measurements, respectively. The results also demonstrated frequent presence and high microcystin concentrations in samples taken during periods of high $P$. rubescens abundance, whereas samples taken during periods of low $P$. rubescens abundance were less frequently microcystin-positive and, when microcystin was present, the quantities detected were low. The latter data therefore suggest that the presence and quantity of microcystin detected in Lake Ammersee seston is strongly if not exclusively correlated with the abundance of $P$. rubescens and moreover that a nearly constant MC: $P$. rubescens biomass ratio predominates in Lake Ammersee. Consequently, variations in microcystin content per unit biomass of seston samples appear strongly dependent on the species composition of the seston sample itself ( $P$. rubescens representation within the sample) rather than a result of variations in $P$. rubescens microcystin content.

$P$. rubescens phycoerythrin content has been shown to be relatively constant; especially as $P$. rubescens shows no photopigment adaptation subsequent to environmental alterations (Skulberg and Skulberg, 1985). Moreover, high intracellular phycoerythrin concentrations appear to be specifically a Planktothrix inherent trait (Ernst et al., 2006b). Therefore, the ratio of MC: phycoerythrin (PE) would appear a better indicator for detection of $P$. rubescens microcystin content than seston biomass in seston samples. Mez (1998) determined PE-concentrations of up to $4 \mu \mathrm{g} \mathrm{I}^{-1}$ during a survey on the abundance of toxic cyanobacteria in Swiss lakes, which would correspond to approximately $4 \mu \mathrm{g} \mathrm{mg}^{-1} \mathrm{dw}$ seston. This compares well with the overall mean

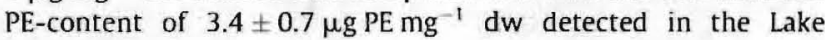
Ammersee seston samples.

The average $\mathrm{MC} / \mathrm{PE}$ ratio as analysed in the Lake Ammersee seston samples was $0.21 \pm 0.03 \mu \mathrm{gMC}-\mathrm{LR}_{\text {equ }} \mu \mathrm{g}^{-1} \mathrm{PE}$ and $0.43 \pm 0.06 \mu \mathrm{g} \mathrm{MC}-\mathrm{LR}_{\text {equ }} \mu \mathrm{g}^{-1}$ PE when analysed via HPLC and Adda-ELISA, respectively. $\mathrm{MC} / \mathrm{PE}$ ratios varied only little, suggesting that the variation in the $P$. rubescens microcystin content was limited. This concurs with observations in other German freshwaters where temporal variability of microcystin variants as well as the variability of relative microcystin amounts within persisting $P$. rubescens blooms was rather low (Fastner et al., 1999a).

\subsection{Oxygen}

Concurrent to prolonged lake stratification and a sustained shift of the thermocline into deeper layers, the oxygen measurements suggested decreasing oxygen-saturation in the metalimnion regularly leading to minimal metalimnic oxygen values in September and October. The observed decrease in available oxygen is assumed to result from a shift of the metalimnion below the euphotic depth, limiting metalimnic photosynthetic activity and thus metalimnic oxygen release, while oxygen consumption due to decomposition of organic matter remained constant (Kucklentz et al., 2001).

In this study, a ranking of the metalimnic oxygen minima according to the lowest values of individual years yielded the following result: $1999<2001<2003<2002$. This ranking compared very well with the ranking obtained with ordering yearly $P$. rubescens abundance from highest to lowest values. The results thus demonstrated that metalimnic oxygen depletion is more pronounced in years of high $P$. rubescens abundance while lower metalimnic depletion could be observable in years with lower $P$. rubescens abundance. Repeated observable metalimnic oxygen depletions therefore appear to be causally related to recurring high $P$. rubescens abundance. This apparent coherence of observations may be assumed to result from oxygen consuming decomposition of senescent $P$. rubescens cells in the metalimnion, e.g. a decline of oxygen saturation was observed subsequent to a decrease in $P$. rubescens abundance coincident with increasing microcystin concentrations in the metalimnic water of Lake Ammersee in August 1999 (Ernst et al., 2001). It may also be caused by a shift of the stratified $P$. rubescens population into deeper layers below the photosynthetic compensations point thus enforcing a change from oxygen producing photosynthesis to respiration of oxygen (Walsby et al., 2001). Similarly, marked metalimnic oxygen depletions have been observed in several other $P$. rubescens-containing lakes (Lindholm and Meriluoto, 1991; Salmaso, 2000; Buzzi, 2002; Krupa and Czernas, 2003), lending more weight to above interpretation.

\subsection{Possible consequences}

Microcystin-containing cyanobacteria have been demonstrated to detrimentally affect various aquatic organisms (Sivonen and Jones, 1999; Wiegand and Pflugmacher, 2005) including fish (Carbis et al., 1996; Fischer and Dietrich, 2000; Tencalla and Dietrich, 1997). This is very interesting as in many pre-alpine $P$. rubescens-containing lakes, coregonids have recently suffered massively reduced growth and changed population demographics resulting in recurrent slumps in yearly yields in coregonid fishery (Wißmath, 2000; Gammeter and Forster, 2002; Müller, 2003; Kirchhofer, 2004).

Laboratory experiments clearly demonstrated adverse effects, including dose- and time-dependent physiological stress and progressive organ damage with subsequent elevated susceptibility to ectoparasitic infestations and increased mortality, following subchronic exposure of coregonids to $P$. rubescens (Ernst et al., 2006a, 2007). This has been shown to apply to $P$. rubescens densities greater than 1500 cells $\mathrm{ml}^{-1}$, which occurred in Lake Ammersee during $47 \%$ of the 261 -week observation period. The results of this study thus suggest that Lake Ammersee coregonids are indeed regularly confronted with potentially adverse $P$. rubescens densities. As the microcystin content of $P$. rubescens appeared to be constant, detrimental effects on the coregonid population resulting from exposure to prolonged $P$. rubescens abundance thus cannot be excluded. This pertains specifically to periods with $P$. rubescens filaments distributed over the entire water column - as for example continuously observable from 

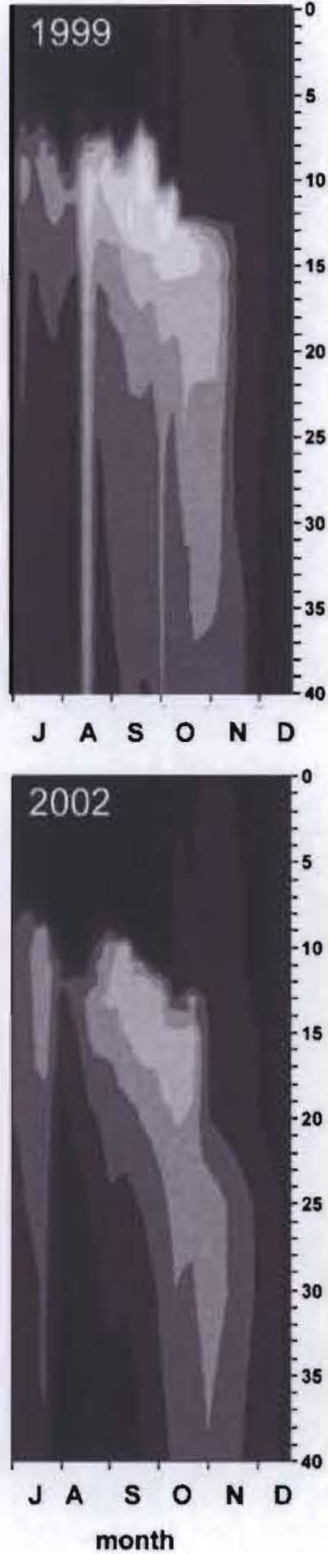
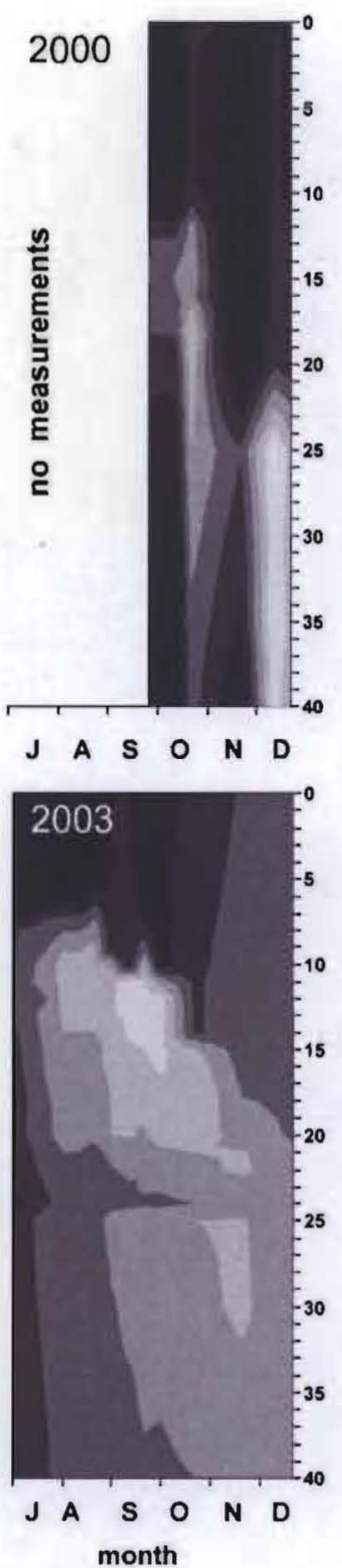
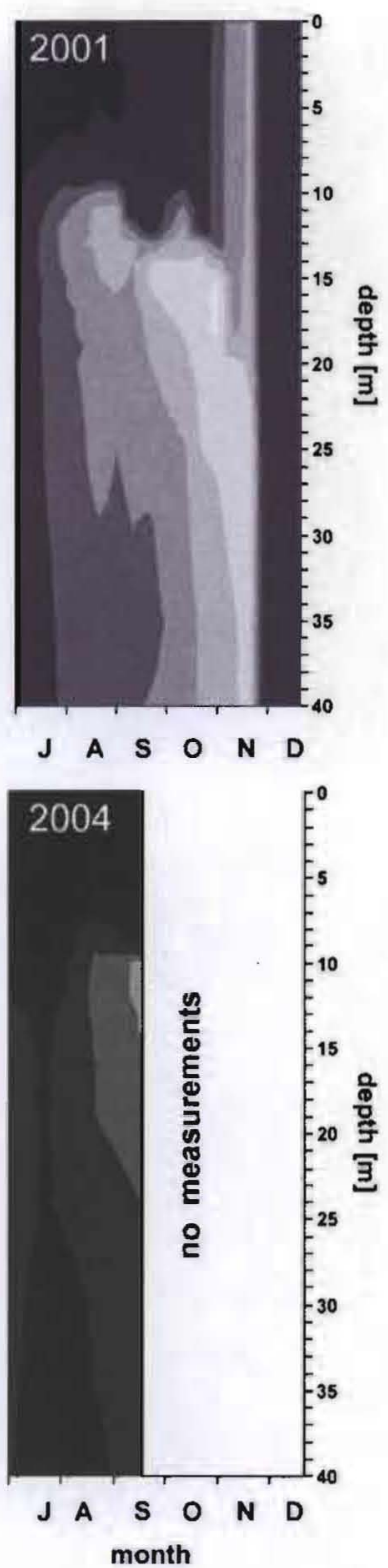

[\% saturation]

- $>100$

- 90-100

- $80-90$

- $70-80$

$\square 60-70$

$\square 50-60$

$\square 40-50$

$\square 30-40$

Fig. 8. Oxygen conditions in the upper $40 \mathrm{~m}$ of Lake Ammersee from July until December (1999-2004).

December 2000 to May 2001 - and thus making avoidance of $P$ rubescens impossible.

As in addition, pronounced metalimnic oxygen depletion has regularly been observed to result in oxygen concentrations at the limit of the coregonid tolerance (Kischnik, 1992; Müller and Stadelmann, 2004), pronounced oxygen depletion may provide a further stress factor in the metalimnic layer. in addition to stratified microcystin-containing $P$. rubescens.

Consequently, it is plausible that the observed challenge of coregonids in $P$. rubescens containing lakes is a result of adverse environmental conditions that are causally linked to the appearance of microcystin-containing $P$. rubescens.

\section{Conclusion}

In summary $P$. rubescens abundance appears to be strongly influenced by water transparency, i.e. illumination in the metalimnion. In addition, the current data support the hypothesis that $P$. rubescens abundance in the re-oligotrophicated Lake Ammersee results from regular phosphate depletion in the epilimnion and possibly benefits additionally from high nitrogen loads. The results as presented thus confirm that the increasing $P$. rubescens abundance in pre-alpine lakes is a paradoxical outcome of lake restoration efforts (Morabito et al., 2002; Jacquet et al., 2005). In addition, the variation in the MC/PE-ratios was low suggesting that the microcystin production of $P$. rubescens in Lake Ammersee is consistent thus indicating that the appearance of $P$. rubescens coincides with measurable microcystin levels. Aquatic organisms such as coregonids thus appear to be regularly confronted with potentially adverse $P$. rubescens densities which might provide a possible explanation for the often observed challenge to coregonid populations in $P$. rubescens containing pre-alpine lakes. 


\section{Acknowledgements}

We would like to thank Prof. K.O. Rothhaupt (University of Konstanz, Germany) for his help in the discussion of limnological issues. The financial support and unflagging interest of the Arthur and Aenne Feindt Foundation (Germany) is highly appreciated.[SS]

\section{References}

Akcaalan, R., Young, F.M., Metcalf, J.S., Morrison, L.F., Albay, M., Codd, G.A., 2006 Microcystin analysis in single filaments of Planktothrix spp. in laboratory cultures and environmental blooms. Water Res. 40, 1583-1590.

Anagnostides, K., Komárek. J.. 1988. Modern approach to the classification of cyanophytes: 3. Oscillatoriales. Arch. Hydrobiol. Suppl. 80, 327-472.

Anneville, O., Souissi, S., Ibanez. F., Ginot, V., Druart, J.C., Angeli, N., 2002. Temporal mapping of phytoplankton assemblages in Lake Geneva: annual and interannual changes in their patterns of succession. Limnol. Oceanogr. 47 (5), 13551366.

Bartram, J., Carmichael, W.W.. Chorus, I., Jones, G., Skulberg, O., 1999. Eutrophication, cyanobacterial blooms and surface scums. In: Chorus, I., Bartram. J. (Eds.). Toxic Cyanobacteria in Water. E \& FN Spon, London.

Bettinetti, R., Morabito, G., Provini, A., 2000. Phytoplankton assemblage structure and dynamics as indicator of the recent trophic and biological evolution of the western basin of Lake Como (N. Italy). Hydrobiologia 435, 177-190.

Blikstad-Halstvedt, C., Rohrlack, T., Andersen, T., Skulberg. O., Edvardsen, B., 2007. Seasonal dynamics and depth distribution of Planktothrix spp. in Lake Steinsfjorden (Norway) related to environmental factors. J. Plankton Res. 29, 471-482.

Blom, J.F., Robinson, J.A. Jüttner, F, 2001. High grazer toxicity of [D-Asp ${ }^{3},(E)$-Dhb? D $^{7}$ microcystin-RR of Planktothrix rubescens as compared to different microcystins. Toxicon 39, 1923-1932.

Bodemer, U., 2004. Variability of phycobiliproteins in cyanobacteria detected by delayed fluorescence excitation spectroscopy and its relevance for the determination of phytoplankton composition of natural water samples. J. Plankton Res. 26, 1147-1162.

Briand, J.F. Jacquet, S., Bernard, C., Humbert, J.F., 2003. Health hazards for terrestrial vertebrates from toxic cyanobacteria in surface water ecosystems. Vet. Res. 34, $361-377$.

Bürgi, H.R., Stadelmann, P., 2002. Change of phytoplankton composition and biodiversity in Lake Sempach before and during restoration. Hydrobiologia 469, 33-48.

Buzzi, F., 2002. Phytoplankton assemblages in two sub-basins of Lake Como. J. Limnol. 61, 117-128.

Carbis, C.R., Rawlin, G.T., Mitchell, G.F., Anderson, J.W., McCauley, I., 1996. The histopathology of carp. Cyprimus carpio L., exposed to microcystins by gavage. immersion and intraperitoneal administration. J. Fish Dis. 19, 199-207.

Dokulil, M., Teubner, K., 2000. Cyanobacterial dominance in lakes. Hydrobiologia $438,1-12$.

Ernst, B., Hitzfeld, B.C., Dietrich, D.R., 2001. Presence of Planktothrix sp. and cyanobacterial toxins in Lake Ammersee, Germany and their impact on whitefish (Coregonus lavaretus L.). Environ. Toxicol. 16, 483-488.

Ernst, B., Hoeger, S., O'Brien, E., Dietrich, D.R., 2007. Physiological stress and pathology in European Whitefish (Coregomus lavaretus) induced by subchronic exposure to environmental relevant densities of Planktothrix rubescens. Aquatic Toxicol. 82, 15-26.

Ernst, B., Hoeger, S.J., O'Brien, E., Dietrich, D.R., 2006a, Oral toxicity of the microcystin-containing cyanobacterium Planktothrix rubescens in European whitefish (Coregonus lavaretus). Aquatic Toxicol. 79, 31-40.

Ernst, B.. Neser, S., O'Brien, E., Hoeger, S.J., Dietrich, D.R., 2006b. Determination of the filamentous cyanobacteria Planktothrix rubescens in environmental water samples using an image processing system. Harmful Algae 5 , 281-289.

Falconer, I.R., 2001. Toxic cyanobacterial bloom problems in Australian waters: risk and impacts on human health. Phycologia 40, 228-233.

Fastner, J., Erhard, M.. Carmichael, W.W., Sun, F., Rinehart, K.L., Rönicke, H., Chorus, 1. 1999a. Characterization and diversity of microcystins in natural blooms and strains of the genera Microcystis and Planktothrix from German freshwater. Arch. Hydrobiol. 145, 147-163.

Fastner, J., Neumann, U., Wirsing. B., Weckesser, J., Wiedner, C.. Nixdorf, B., Chorus, I. 1999b. Microcystins (Hepatotoxic Heptapeptides) in German fresh water bodies. Environ. Toxicol. 14, 13-22.

Feuillade, J., 1994. The cyanobacterium (blue-green alga) Oscillatoria rubescens D.C. Arch. Hydrobiol. Beih. Ergebn. Limnol. 41, 77-93.

Fischer, W.J., Garthwaite, I. Miles, C.O., Ross, K.M., Aggen, J.B., Chamberlin, A.R., Towers, N.R., Dietrich, D.R., 2001. Congener-independent immunoassay for microcystins and nodularins. Environ. Sci. Technol. 35, 4753-4757.

Fischer, W. J. Dietrich, D.R., 2000. Pathological and biochemical characterization of microcystin-induced hepatopancreas and kidney damage in carp (Cyprinus carpio). Toxicol. Appl. Pharm. 164, 73-81.

Gammeter, S., Forster, R., 2002. Langzeituntersuchungen im Zürichobersee. Wasserversorgung Zürich, Zürich.

Geitler, L., 1932. Cyanophyceae. Johnson Reprint Cooperation, Berlin.
Grach-Pogrebinsky. O., Sedmak. B., Carmeli, S., 2003. Protease inhibitors from Slovenian Lake Bled toxic waterbloom of the cyanobacterium Planktothrix rubescens. Tetrahedron 59, 8329-8336.

Grimminger, H., 1982. Verzeichnis der Seen in Bayern - Teil 1, Bayerisches Landesamt für Wasserwirtschaft, München.

Hoeger, S.J. Hitzfeld, B.C.. Dietrich, D.R., 2005. Occurrence and elimination of cyanobacterial toxins in drinking water treatment plants. Toxicol. Appl. Pharm. 203, 231-242.

Hoeger, S.]., Schmid, D., Blom, J.F., Ernst, B., Dietrich, D.R., 2007. Analytical and functional characterization of microcystins [Asp3] MC-RR and [Asp3,Dhb7]MCRR: consequences for risk assessment? Environ. Sci. Technol. 41, 2609-2616

Jacquet, S., Briand. J.F. Leboulanger, C., Avois-Jacquet, C.. Oberhaus, L., Tassin, B. Vincon-Leite, B., Paolini, G., Druart. J.C., Anneville, O., Humbert, J.F., 2005. The proliferation of the toxic cyanobacterium Planktothrix rubescens following restoration of the largest natural French lake (Lac du Bourget). Harmful Algae 4. 651-672.

Jann-Para, G.C., Schwob, I., Feuillade, M., 2004. Occurrence of toxic Planktothrix rubescens blooms in lake Nantua, France. Toxicon 43, 279-285.

Kärntner Seenberichte, 2000-2007. Kärntner Institut für Seenforschung. Klagenfurt, Austria.

Kirchhofer, A. 2004. Monitoring der Felchenfänge der Berufsfischer von Brienzersee, Thunersee und Bielersee 1984-2003. WFN - Wasser Fisch Natur, Gümmenen.

Kischnik, P., 1992. The coregonids of Lake Lacher See. Arch. Hydrobiol, Beih. Ergebn. Limnol. 38, 273-294.

Krupa, D., Czernas, K., 2003. Mass appearance of cyanobacterium Plonktothrix rubescens in Lake Piaseczno, Poland. Water Qual. Res. J. Canada 38, 141-152.

Kucklentz, V., Hamın, A., Jöhnk, K., Tsang-Pi, C., Morscheid, H., Roth, D., SchmidtHalewicz, S., Morscheid, H., Mayr, C., 2001. Antwort bayerischer Voralpenseen auf verringerte Nährstoffzufuhr. Bayerisches Landesamt für Wasserwirtschaft, München.

Kurmayer, R., Christiansen, G., Fastner, J., Börner, T., 2004. Abundance of active and inactive microcystin genotypes in populations of the toxic cyanobacterium Planktothrix spp. Environ. Microbiol. 6 (8), 831-841.

Kurmayer, R., Christiansen, G., Gumpenberger, M., Fastner, J., 2005. Genetic identification of microcystin ecocypes in toxic cyanobacteria of the genus Planktothrix. Microbiology 151, 1525-1533.

Lawton, L.A., Edwards, C., Codd, G.A., 1994. Extraction and high-performance liquidchromatographic method for the determination of microcystins in raw and treated waters. Analyst 119, 1525-1530.

Leboulanger. C., Dorigo, U., Jacquet, S., Le Berre, B., Paolini, G., Humbert, J.F., 2002 Application of a submersible spectrofluorometer for rapid monitoring of freshwater cyanobacterial blooms: a case study. Aquat. Microb. Ecol. 30, 83-89.

Legnani, E., Copetti, D., Oggioni, A., Tartari, G., Palumbo, M.T., Morabito, G., 2005. Planktothrix rubescens seasonal dynamics and vertical distribution in Lake Pusiano (North Italy). J. Limnol, 64, 61-73.

Lemmin, U., 1978. Lakes, Chemistry. Geology. Physics, Springer Verlag.

Lindholm, T., Meriluoto, J.A.O., 1991. Recurrent depth maxima of the hepatotoxic Cyanobacterium Oscillatoria agardhii. Can. J. Fish. Aqu. Sci. 48, 1629-1634.

Luukkainen, R., Sivonen, K., Namikoshi, M., Fardig. M., Rinehart, K.L., Niemela, S.I 1993. Isolation and identification of eight microcystins from thirteen Oscillotoria agardhii strains and structure of a new microcystin. Appl. Environ. Microb. $59,2204-2209$

Malbrouck, C., Kestemont, P., 2006. Effects of microcystins on fish. Environ. Toxicol. Chem. 25, 72-86.

Mez, K., 1998. Erste Untersuchungen über toxische Cyanobakterien in Schweize Mittelland- und Voralpenseen, Institut für Pflanzenbiologie/Mikrobiologie, Zürich.

Micheletri, S., Schanz, F., Walsby. A.E., 1998. The daily integral of photosynthesis by Planktothrix rubescens during summer stratification and autumnal mixing in Lake Zürich. New Phytol, 139, 233-246.

Morabito, G., Ruggiu, D., Panzani, P., 2002. Recent dynamics (1995-1999) of the phytoplankton assemblages in Lago Maggiore as a basic tool for defining association patterns in the Italian deep lakes. J. Limnol. 61. 129-145.

Müller, R., 2003. Populationsdynamische Untersuchungen an den Felchen des Brienzersees, EAWAG, Forschungszentrum für Limnologie, Kastanienbaum.

Müller, R., Stadelmann, P., 2004. Fish babitat requirements as the basis for rehabilitation of eutrophic lakes by oxygenation. Fisheries Manage. Fcol. 11. 251260.

Mur, L.R., Schreurs, H., 1995. Light as a selective factor in the distribution of phytoplankton species. Water Sci. Technol. 32, 25-34.

Mur, L.R., Skulberg, O., Utkilen, H., 1999. Cyanobacteria in the environment. In: Chorus, I., Bartram, J. (Eds.). Toxic Cyanobacteria in Water. Springer, Berlin.

Nixdorf, B., Hemm. M., Hoffmann, A., Richter, P., 2004. Dokumentation von Zustand und Entwicklung der wichtigsten Seen Deutschlands; Teil 11: Bayern, Umweltbundesamt Berlin

Ochsenbein, U., Mattmann, B., 2003. Gewässerbericht 1997-2000. Amt für Gewässerschutz und Abfallwirtschaft, Bern.

Salmaso, N., 2000. Factors affecting the seasonality and distribution of cyanobacteria and chlorophytes: a case study from the large lakes south of the Alps with special reference to Lake Garda. Hydrobilogia 438, 43-63.

Salmaso, N.. 2002. Ecological patterns of phytoplankton assemblages in Lake Garda: seasonal, spatial and historical features. J. Limnol, 61, 95-115.

Sivonen, K., Jones, G., 1999. Cyanobacterial toxins. In: Chorus, I., Bartram, J. (Eds.), Toxic Cyanobacteria in Water. Springer, Berlin. 
Skulberg. O., Skulberg. R., 1985. Planctic species of Oscillatoria (Cyanophyceae) from Norway. Arch. Hydrobiol. Suppl. 71, 157-174.

Suda, S., Watanabe, M.M., Otsuka, S., Mahakahant, A., Yongmanitchai, W., Nopartnaraporn, N., Liu, Y., Day.J.D., 2002. Taxonomic revision of water-bloom forming species of oscillatorioid cyanobacteria. Int. J. Syst. Evol. Micr. 52, 1577-1595.

Tandeau de Marsac, N., 1977. Occurrence and nature of chromatic adaptation in cyanobacteria. J. Bacteriol. 130, 82-91.

Tencalla, F., Dietrich, D.R., 1997. Biochemical characterization of microcystin toxicity in rainbow trout (Oncorhynchus mykiss). Toxicon 35, 583-595.

Teubner, K., Morscheid, H., Tolloti, M., Greisberger, S., Morscheid, H., Kucklentz, V., 2004. Bedingungen für das Auftreten toxinbildender Balualgen (Cyanobakterien) in bayerischen Seen und anderen stehenden Gewässern, Bayerisches Landesanit für Wasserwirtschaft, München.

Walsby, A.E., Avery, A., Schanz, F., 1998. The critical pressures of gas vesicles in Planktothrix rubescens in relation to the depth of winter mixing in Lake Zürich, Switzerland. J. Plankton Res. 20, 1357-1375.
Walsby, A.E., Dubinsky, Z., Kromkamp, J.C.. Lehman, C., Schanz, F., 2001. The effect of diel changes in photosynthetic coefficients and depth of Planktothrix rubescens on the daily integral of photosynthesis in Lake Zürich. Aquatic Sci. 63, 326349.

Walsby, A.E.. Schanz, F.. 2002. Light-dependent growth rate determines changes in the population of Planktothrix rubescens over the annual cycle in Lake Zürich, Switzerland. New Phytol. 154, 671-687.

Wiegand, C., Pflugmacher, S., 2005. Ecotoxicological effects of selected cyanobacterial secondary metabalites: a short review. Toxicol. Appl. Pharm. 203, 201218.

Wißmath, P., 2000. Die Entwicklung der Renkenbestände im Ammersec und die Auswirkungen auf die fischereiliche Bewirtschaftung. Münchner Beiträge zur Abwasser-, Fischerei- und Flussbiologie 53, 399-401.

Zotina, T., Köster, O., Jüttner, F., 2003. Photoheterotrophy and light-dependent uptake of organic and organic nitrogenous compounds by Planktothrix rubescens under low irradiance. Freshwater Biol. 48, 1859-1872. 